Fall 2008

\title{
Community-based multicultural counselor preparation as a site of Praxis and social justice
}

\author{
Nola Butler-Byrd \\ San Diego State University \\ Jesús Nieto \\ San Diego State University \\ Maria Nieto Senour \\ San Diego State University
}

Follow this and additional works at: https://digitalscholarship.unlv.edu/jpme

\section{Repository Citation}

Butler-Byrd, Nola; Nieto, Jesús; and Senour, Maria Nieto (2008) "Community-based multicultural counselor preparation as a site of Praxis and social justice," Journal of Praxis in Multicultural Education: Vol. 3: No. 1, Article 2. DOI: $10.9741 / 2161-2978.1010$

Available at: https://digitalscholarship.unlv.edu/jpme/vol3/iss1/2

This Article is protected by copyright and/or related rights. It has been brought to you by Digital Scholarship@UNLV with permission from the rights-holder(s). You are free to use this Article in any way that is permitted by the copyright and related rights legislation that applies to your use. For other uses you need to obtain permission from the rights-holder(s) directly, unless additional rights are indicated by a Creative Commons license in the record and/ or on the work itself.

This Article has been accepted for inclusion in Journal of Praxis in Multicultural Education by an authorized administrator of Digital Scholarship@UNLV. For more information, please contact digitalscholarship@unlv.edu. 


\title{
Community-Based Multicultural Counselor Preparation as a Site of Praxis and Social Justice
}

\author{
Nola Butler-Byrd, Jesús Nieto, and Maria Nieto Senour
}

Recent calls in counseling psychology to embrace social justice work and mandates in the field to operationalize multicultural competencies have offered few mature examples of how this work actually looks. This article describes a 35-year-old program in a community-based urban setting which has successfully prepared over 800 counselors while integrating social justice and multicultural competencies into its core curriculum. The authors discuss the impact of the program in terms of multicultural competence, praxis, and social justice agency. The article includes recommendations about challenges that professionals and programs of this nature must negotiate in order to implement a program of this nature effectively.

Demographic trends, immigration patterns, social conditions, and political circumstances have created vibrant ethnic, linguistic, and experiential diversity in the United States (Gay, 2003-04). This cultural richness and its ensuing tensions have also led to the development of significant social justice issues with implications for all social arenas and professions including the fields of education and counseling psychology.

According to Ponterotto (1997), a model multicultural counseling program should have a critical mass of students and faculty of color, present various world views and ways of knowing and learning, have faculty who see multicultural issues as central to their teaching and research and who are involved in ongoing education regarding diversity issues, and have the support of key administrators around multicultural concerns. Nonetheless, most counselor preparation programs continue to have a Western monocultural focus, although students experience courses differently based on their race, ethnicity, gender, sexual orientation, and other group identities (Sfeir-Younis, 1995).

Nola Butler-Byrd is an assistant professor in the Community-Based Block Program in the Department of Counseling and School Psychology, College of Education at San Diego State University. Her research interests include experiential multicultural education and counseling, transformative social justice, and multicultural identity development. Jesús Nieto is an associate professor of teacher education, College of Education at San Diego State University. His research interests are experiential multicultural education for teachers and counselors with an emphasis on diversity (gender, ethnicity, age, disability, socioeconomics, homelessness, sexual orientation, etc.), power, war, and compassion. Maria Nieto Senour is a professor in the Community-Based Block Program in the Department of Counseling and School Psychology, College of Education at San Diego State University. Her research interests are experiential multicultural counselor education, gender roles and ethnicity, and the psychology of the Chicana. 
Purpose

The impetus for a stronger social justice orientation in the field and mandates for multicultural competence have raised awareness and passion and created goals and ideals for counseling and psychology. However, few scholars have provided examples of successful, mature programs with a social justice orientation (Goodman, Liang, Helms, Latta, Sparks \& Weintraub, 2004). This article accomplishes the foregoing by describing the Community-Based Block (CBB) counselor preparation program, its students, alumni and faculty, three of who are authors of this study. Recommendations for implementing a similar program are included.

\section{The Community-Based Block Program as a Site of Praxis}

\section{History, Mission, and Overview}

The CBB program is a yearlong graduate program offering a 30-unit MA in Education with a concentration in counseling. The 35-year-old program is housed in the Department of Counseling and School Psychology in the College of Education at San Diego State University (SDSU), where it has received substantial support over the years, as well as faced significant challenges as a non-traditional program in a traditional university. Training practitioners who are committed to working with marginalized individuals and communities conceived it with a strong social justice orientation in order to address the critical need for competent multicultural counselors in urban environments.

Since its inception, the CBB program has negotiated the tension between standards imposed by external conservative forces and the program's philosophical orientation. This pedagogy incorporates deliberative democratic processes with affective experiential multicultural education theory and works to minimize the traditional hierarchy between students and faculty and develop a truly collaborative learning community where power is shared and students are intimately involved in decision making processes related to their learning and professional development. Facing an accountability initiative in 1973, CBB founder Dave Malcolm developed a set of four objectives for himself, not the students. These objectives were assessed by faculty and students on an ongoing basis as part of the community's developmental process:

"(a) I will give the learners access not only to my expertise but also to myself as a person and to my experiences. (b) I will do all I can to suggest (but not require) experiences-materials to read, things to do, people to touch, processes to observe, ideas to ponder, practices to try, whatever-that the learners might not otherwise have thought of, thereby increasing the options 
open to them. (c) I will respect each learner's autonomy and freedom, including the freedom to fail. and (d) I will give up the power that goes with "gate keeping" and in its place I will give each learner honest feedback as straight as possible, to the best of my ability, in whatever areas the learner desires" (Malcolm, 2003, Part I-B, p.5).

The standards and assessment movement influenced by No Child Left Behind (NCLB) is the most recent manifestation of the colonizing and disempowering effects of positivist inquiry that has negatively affected marginalized communities under the guise of litigating equality. The SDSU College of Education developed an assessment plan in 2002 to encourage programs to self-determine their own assessment processes and learning outcomes instead of waiting for them to be imposed in the hope of avoiding the fate that K-12 schools have experienced as a result of NCLB. As with previous initiatives, CBB struggled with a philosophical dilemma, which was shared with faculty, students, alumni, the department, and the CBB advisory committee. The program spent many hours deliberating the costs and benefits of assessment, researching the needs of the individuals and communities served, searching for pedagogically compatible options, reflecting on program history, and visioning the program's future. The biggest concern was the potential loss of the powersharing and collaborative decision-making aspects of the program. Out of this struggle, the program developed the following four learning outcomes and objectives, thus articulating a clearer sense of identity and self-definition. It was decided that students would demonstrate competence in (a) conceptualizing various counseling theories, models, and methods from a multicultural perspective and a transformative paradigm and applying them in counseling practice and research; (b) integrating multicultural knowledge and experience into counseling theory, practice, and research; (c) integrating social justice and advocacy into counseling theory, practice, and research; (d) practicing selfawareness and personal insight that support professional growth and development in the interest of clients and communities. Each goal has specific performance objectives and measures associated with it, which are aligned with counseling psychology multicultural competencies (Arredondo \& Perez, 2003) and social justice principles defined by Goodman, et al. (2004).

\section{Program Admissions Process and Sequence of Study}

Each year, a group of 24-27 students is admitted through a rigorous selection process that is designed to screen for strong academic skills, desired personal attributes, interpersonal skills, multicultural experience and a social justice orientation. This selection process includes a review of written portfolios and 
academic work and group interviews that utilize some of the experiential processes that take place in the program.

The sequence of study (which includes such subject areas as counseling theories and process, multicultural dimensions of counseling, law and ethics, and research) is designed to allow learners to build a theoretical and practical understanding of the counseling process, to deeply understand the sociocultural and other systems factors influencing their clients' mental health and well-being, to learn to use research in the interests of social justice, and to get real experience in doing counseling in multiple supervised clinical settings.

Students and faculty meet for approximately 20 hours a week, as contrasted with traditional individual classes. Included in the experiential aspect of the program is live supervision of counseling sessions by faculty in a six-hour practicum during which students frequently work with clients who do not speak English and face the many obstacles that come with poverty. Students are engaged in a fieldwork component, a minimum of 10 hours a week, in which they work under the supervision of practitioners in the field of the students' interests in urban, diverse settings that serve oppressed communities. Almost all of the learning experiences are team-taught or facilitated by two or more faculty working with large and small groups of students. The program is characterized by the following five components: (a) diverse communities, (b) voice, (c) power sharing and student empowerment, (d) consciousness raising, and (e) selfawareness and self-examination.

\section{Building Diverse Communities}

Since its inception, the CBB program has attracted highly diverse students and faculty and has grown increasingly more diverse over the years. CBB student cohorts have always been composed of at least two-thirds students of color. Initially, the majority was African American and Latina/o/Chicana/o students, with one-third Euroamerican; however, over time, growing numbers of Asian/Pacific Islander, Middle Eastern, American Indian students and other ethnically diverse students have been members of CBB learning communities. $\mathrm{CBB}$ has also attracted international students from Asia, Africa, Europe, the Middle East, and Mexico. Between 2003 and 2006 over 50\% of CBB students were first or second generation immigrants. Sexual orientation, physical ability or disability and other areas of diversity have also typically been included in student cohorts. Of the three CBB core faculty, there has always been at least one African American and one Latino/a. The numbers and ethnicities of CBB part-time faculty have varied over time, but have always included ethically diverse people of color.

Consonant with the program's experiential foundation, CBB meets in a community counseling clinic and a public library in two of the city's most 
ethnically diverse, low-socioeconomic communities, as well as on the university campus. This immerses participants in the communities they serve, requiring them to come face-to-face with the consequences of being part of a challenged community.

\section{Voice}

Most CBB students were born and raised in disenfranchised communities where their voices were muted or silenced because they were people of color, lesbian, gay, bisexual, transgender, and/or female living in a Euroamerican male dominated society. Many have issues with identity, power, and self-expression because of these experiences and/or resultant painful experiences with their troubled families or in academia where they often felt silenced or unappreciated. The program focuses a great deal on helping students understand these issues of oppression through a multicultural and feminist perspective, while supporting them in finding and expressing themselves orally and in writing in ways that are appropriate for them as individuals in the context of their cultures. Simultaneously, the program helps students learn how to assist their clients in finding their voices through counseling, and it teaches them how to conduct scholarship that voices and addresses the issues and concerns of marginalized people. Cultural context, gender, and social location and their intersections are all examined as part of this process of identity development and clarification.

\section{Power Sharing and Student Empowerment}

The program's critical multicultural pedagogy utilizes a person-centered approach that places a strong emphasis on practitioner self-awareness, and interpersonal and relationship-building skills. These areas are considered integral to multicultural counseling competence (Sevig \& Etzkorn, 2001, Arredondo \& Arciniega, 2001). The program's democratic learning community is structured in a "block" format where all students meet with a team of faculty and engage in consensus decision-making. Advocates of social justice education and multicultural counselor training have raised questions about the power inequality that exists in traditional faculty-student roles and have encouraged greater power sharing (Goodman, et al., 2004; Nagda, Gurin, \& Lopez, 2003). CBB creates an educational environment that strives for social justice by collapsing the hierarchy between students and faculty and encouraging students to take an active role in designing and implementing their learning process. This includes students working with faculty to develop collaborative syllabi, curriculum and grading processes, and designing shared learning and group processes. 


\section{Consciousness Raising}

Every year, students express a strong desire for the inclusion of social justice issues and activism throughout the program. Topics include racial and gender bias in research, standardized test bias, domestic violence, violence against women, homelessness, poverty, war, and global spending priorities. These topics have been addressed through collaborative knowledge sharing by faculty and students who have expertise in specific issues, guest speakers, experiential activities, cultural plunges, quizzes, lectures, videos, and discussions. Students work with faculty to develop research projects, which focus on social justice issues about which they have a passion. In addition to working in diverse field placements with marginalized individuals and communities, students often take the initiative to plan and implement a variety of social activism projects such as preparing and distributing hundreds of lunches to homeless people and taking clothing and other supplies to impoverished people. Social justice coursework and activism inform one another.

\section{Self-Awareness and Self-Examination}

In listing the six principles that counseling psychologists should consider if they are to engage in social justice work Goodman et al. (2004) start with ongoing self-examination. The CBB program has always stimulated student self examination and increased self awareness by virtue of creating diverse student cohorts that are free to help construct their learning processes. When issues of race, ethnicity, sexual orientation and/or class are raised for discussion, they invariably stir strong emotional responses in all participants. Goodman et al. (2004) speak to the importance of faculty modeling of ongoing self-examination as a means of helping to create a safe space for students to take similar risks. Early on CBB faculty expressed an assumption that everyone, they included, was biased and held racial and sexual stereotypes. The founder of the CBB program would often refer to himself as a "recovering" racist, sexist, homophobe, etc. He worked diligently to examine himself and was open to feedback from women students, LGBT students, and students of color. This helped to create a safe space for students and other faculty colleagues in which to hold what have been called "difficult conversations" and for the exploration of biases and assumptions.

\section{Assessing Program Effectiveness}

The CBB program has successfully prepared over 800 counselors during its 35 years. Multiple direct measures are used annually to assess the CBB program. In 
order to determine the achievement of student learning goals, students are required to complete and pass four written comprehensive examinations and one oral examination in: Counseling Theory, Multicultural Healing, Self-of-theCounselor, Research, and Law and Ethics. Each written examination is submitted to and evaluated by program faculty. Since CBB's philosophy includes student empowerment, faculty work with students, many of who have been mis-educated and from whom little has been expected in the past, to help them achieve high standards. Students are allowed to re-write their papers and to re-take their oral examination until they reach a satisfactory level of competence. All examinations, fieldwork and practica are evaluated by rubrics, which were collaboratively developed with students (see example in Appendix B: Self-of-the-Counselor Comprehensive Examination).

Indirect assessment measures of program effectiveness include an annual department exit survey, alumni outcomes surveys (most recently conducted in 2004 and 2005), academic reviews that are conducted every six years by external sources (most recently conducted in 2006), and other qualitative and quantitative studies involving students, alumni, and employers. The large majority of 146 CBB alumni who participated in the 2005 Survey of $C B B$ Graduates (Nieto \& Senour, 2005) indicated that they use what they learned in CBB at their jobs each day 4.63 (.62) and in their personal lives 4.55 (.70) on a scale of 1 (strongly disagree) to 5 (strongly agree). See Table 1 for other perceptions from participants in this survey and themes that emerged from the analysis below. Results from the 2004 CSP Outcomes Study (RobinsonZanartu, Cook-Morales, Terry, \& Senour, 2004) described very similar positive outcomes. Two surveys of employers/supervisors of CBB graduates also yielded highly favorable perceptions of graduates' performance on the job (Senour, 1998 and 2006).

\section{Interest/Skills Strengthening}

One section of the Survey of CBB Graduates (Nieto \& Senour, 2005) assessed the extent to which participants felt that $\mathrm{CBB}$ strengthened their interest and skills in seven areas: 1) counseling/communication skills, 2) self-awareness, 3) group dynamics, 4) creating a sense of community in a class/group, 5) student empowerment/non-hierarchy, 6) coalition building, and 7) social justice. The means of all seven items were high, ranging from 4.19 to 4.76 . The two highest means were 4.74 (.58) for "counseling/communications skills," and 4.75 (.57) for "self-awareness." 
Table 1

Mean Perceptions of 2005 CBB Graduate Survey Participants

$\begin{array}{lc}\text { ABC strengthened my interest/skills in... } & \text { M (SD) } \\ \text { 1. Counseling/communication skills } & 4.74(.58) \\ \text { 2. Self-awareness } & 4.75(.57) \\ \text { 3. Group dynamics } & 4.71(.54) \\ \text { 4. Creating a sense of community in a class/group } & 4.62(.77) \\ \text { 5. Student empowerment/non-hierarchy } & 4.45(.74) \\ \text { 6. Coalition building } & 4.18(.82) \\ \text { 7. Social justice } & 4.51(.65) \\ \text { ABC prepared me to deal with... } & \\ \text { 8. Racism/discrimination } & 4.42(.84) \\ \text { 9. Sexism/violence against women } & 4.24(.90) \\ \text { 10. Classism/poverty } & 4.24(.93) \\ \text { 11. Homophobia/Gay-lesbian issues } & 4.42(.81) \\ \text { 12. Ablism/physical disability issues } & 3.71(1.02) \\ \text { 13. My own personal/interpersonal issues } & 4.63(.63) \\ \text { 14. Social issues } & 4.51(.69) \\ \text { Overall Impact } & \\ \text { 15. I have recommended ABC to others } & 4.72(.62) \\ \text { 18. ABC was the most important year of my life } & 3.94(1.12)\end{array}$

Note. $\mathrm{N}=146$. Ratings Code: $1=$ Strongly Disagree; $5=$ Strongly Agree.

\section{Preparation for Dealing with Various Issues}

Another section of the 2005 survey assessed the extent to which CBB alumni felt they were prepared to deal with seven key areas: 1) racism/discrimination, 2) sexism/violence against women, 3) classism/poverty, 4) homophobia/gaylesbian issues, 5) ablism/physical disability issues, 6) my own personal/interpersonal issues, and 7) social issues. With the exception of item 12 ("ablism/physical disability issues"), all items in this section had means well above 4.0. The highest mean, 4.63 (.63), was for item 13, "my own personal/interpersonal issues."

\section{Ongoing Impact on Professional and Personal Life}

Finally, the 2005 survey assessed CBB's overall impact on participants in the following areas: (a) recommending CBB to others, (b) use of what was learned 
in $\mathrm{CBB}$ each day on the job, (c) use of what was learned in CBB each day on a personal level, and (d) the importance of CBB in a participant's life. The highest means in this section were 4.63 (.62) for Item 16 "I use what I learned in CBB each day (job)," and 4.55 (.70) for item 17 "I use what I learned in CBB each day (personal)."

\section{CBB Alumni Outcomes: Education and Employment}

High percentages of the over $800 \mathrm{CBB}$ alumni are accepted into further graduate training and doctoral programs. Typically, some $40 \%$ to $50 \%$ of each year's graduates go on to receive school counseling and school psychology credentials or MFT licensure preparation. Approximately one fourth of alumni have gone on for doctoral degrees. Longitudinal outcomes studies (Nieto \& Senour, 2005; Robinson-Zanartu, Cook-Morales, Terry, \& Senour, 2004), demonstrate that CBB graduates often emerge in leadership positions; alumni include a college presidency, deanships, presidency of a faculty union and several in elected office. One group of alumni designed and is operating an urban African-centered charter school. Results of employer surveys demonstrate high employer satisfaction with graduates' counseling and professional skills, sensitivity to issues of diversity, advocacy for social justice issues, and leadership (Senour, 1998).

In 2006 Senour conducted an online survey of employers and supervisors of CBB graduates. All alumni for whom Senour had email addresses were asked to forward a link to the survey to any employers or supervisors who had employed or supervised two or more CBB graduates. The survey asked for anonymous feedback on general counseling competence, multicultural competence and social justice advocacy. Sixty-two employers and supervisors responded. When asked "Has your general experience with CBB graduates been positive?" the mean score and standard deviation was $4.81(.44)$ on a five-point scale. On "Do/did they possess counseling competence?" employers rated them 4.61 (.64). On "Do/did they possess multi-cultural competence?" the score was 4.87 (.34) and on "Are/were they advocates for social justice?" employers rated them 4.7 (.49). One employer stated,

\footnotetext{
"Many of the CBB'ers that I've worked with have been self-starters and come to my site with many counseling skills already. They are extremely self-reflective and have a great grasp of working with children and their families. CBB'ers tend to have a strong understanding of how their own personal and cultural histories influence their work with others. Possessing a strong sense of political consciousness has also been a trend with the CBB'ers that I've been privileged to work with."
} 
These results are consistent with the other measures used to assess the effectiveness of CBB graduates and an External Review Team's Report for the 2006 Department of Counseling and School Psychology's Academic Review (Carey \& Cheng, 2006). Reviewers reported that,

"The CBB program operates on principles that are highly effective in developing 'first-generation' graduate students for careers and for further graduate education.... The high quality of practical training was strongly affirmed by graduates and viewed as a competitive edge in the job market. A very large number of graduates attended a [n academic review] session and expressed their strong support for this model and they applauded the efforts of the faculty for providing such a unique and effective collaborative education experience."

\section{Challenges and Recommendations}

The CBB program is currently negotiating three significant challenges that are also discussed in the literature: (a) emotional costs, (b) professional consequences, and (c) pressure from licensing and accreditation requirements.

\section{Emotional Costs}

Kiselica \& Robinson (2001) describe the emotional cost of social justice work as the greatest challenge in this type of work for students as well as faculty. The stress from dealing with very difficult issues and situations and, at times, the sense of powerlessness is very difficult to negotiate. This is compounded by the time and energy intensity of the work that often goes unnoticed and unrewarded. It is also very challenging to figure out how to balance confrontation with engagement when dealing with unjust systems and practices. Speaking up or taking action in unjust situations to make changes for the betterment of the less powerful can be very frustrating and anger producing. The CBB program has received feedback from the field that $\mathrm{CBB}$ graduates are highly effective in confronting unjust systems and practices, however they sometimes distance potential allies because they have problems negotiating their frustrations. The program is committed to refining teaching strategies around social justice advocacy and to developing a support system for CBB alumni through the CBB alumni association.

\section{Professional Consequences}

Goodman, et al. (2004) describe the professional consequences of social justice work. Social justice work is time and resource intensive, especially research and 
practice that is ethically sound and multiculturally competent, by comparison to traditional research and practice. In addition, developing student self-awareness and creating a non-hierarchical learning community require team-teaching. CBB faculty have found that the tenure-track process in academia is not sensitive to this significant factor; instead, it pressures the program to change to reduce faculty work load and expects tenure-track faculty to publish in peer-reviewed journals, the majority of which only accept traditional research.

\section{Pressure from Licensing and Accreditation Requirements}

Talleyrand, et al. (2006) and Goodman, et al. (2004) discuss the challenges that licensing and accreditation requirements place on counseling psychology programs to fulfill traditional, individual psychotherapy models, which make it very difficult to implement social justice work and multiculturally competent healing models. In the past, the CBB program was able to easily negotiate the transfer of program course work to other programs in the CSP department and other university programs. Since accreditation and licensing requirements have intensified, this process is becoming more and more difficult, which means that less coursework from $\mathrm{CBB}$ is transferred and education is becoming more expensive and time intensive for $\mathrm{CBB}$ graduates. These issues have been challenging for $\mathrm{CBB}$ faculty as well as students.

However, these challenges are not unique to CBB. Toporek, Gerstein, Fouad, Roysircar, and Israel (2006) discuss their experience that in counseling psychology social justice work "involves a level of personal commitment and skill that goes beyond the typical professional scope ... [and make] recommendations for personal development [that include] the need for mentors and role models, supportive networks, self-awareness and reflection, personal involvement in communities, and travel and immersion experiences" (p. 548).

Given the success of the Community Based Block at preparing culturally diverse students to become effective counselors/social justice change agents with culturally diverse clients and communities, the authors wish to make the following recommendations regarding the structure and approaches of counselor education programs: (a) Perhaps the most important element of CBB's success is the participation of culturally diverse faculty and students. It is essential that counselor education programs reflect the diversity of their future clients in the composition of program faculty and students. The importance of prioritizing such diversity can hardly be overstated. (b) Self-awareness in counselors is paramount for the successful facilitation of increasing selfawareness in clients. Consequently, it is essential that program activities maintain a strong focus on the cultivation of self-awareness of students. Faculty not only need to possess appropriate skills but they need to model constant efforts to increase their own self-awareness, just as counselors must model 
appropriate behavior for their clients. (c) A student-centered approach to counselor preparation appears to yield great benefits in terms of student selfconfidence, self-efficacy, and critical thinking skills by virtue of the fact that it emphasizes students' ability to make important choices. Thus, it is very important to maximize student participation in the design of program curriculum and activities, recruitment and selection of future students, and related decisionmaking. (d) Holding classes in the community, rather than on campus, demonstrates a strong commitment to placing clients' needs and concerns at the center of program activities. This approach provides exposure to clients' daily living conditions and fosters interest in social justice by allowing students to personally witness inequities in terms of resources available to diverse populations.

\section{Conclusion}

It is hoped that these recommendations and the sharing of information about the CBB program model and its effectiveness regarding the preparation of multiculturally competent counselors can benefit the field of counselor preparation. The CBB program's strong focus on cultural diversity, selfawareness, social justice, and unusually high degree of student empowerment may have something important to offer the field, and this article will hopefully invite other counselor preparation programs to examine some of CBB's methods and approaches. The authors welcome inquiries.

\section{References}

Arredondo, P. \& Arciniega, G.M. (2001). Strategies and Techniques for Counselor Training Based on Multicultural Counseling Competencies. Journal of Multicultural Counseling and Development, 29, 263-273.

Carey, J. \& Cheng, L. (2006). External review team's report: Department of Counseling and School Psychology Academic Review. San Diego, California: San Diego State University.

Gay, G. (2003-04). The importance of multicultural education. Educational Leadership, 61(4), 30-35.

Goodman, L.A., Liang, B., Helms, J.E., Latta, R.E., Sparks, E., Weintraub, S.R. (2004) Training counseling psychologists as social justice agents: Feminist and multicultural principles in action. The counseling psychologist, 32(6), 793-837.

Kiselica, M. S., \& Robinson, M. (2001). Bringing advocacy counseling to life: The history, issues, and human dramas of social justice work in counseling. Journal of counseling and development, 79(4), 387-398. 
Malcolm, D. (2003). Herstory and history...the CBB story: Six chapters from an unpublished manuscript that at that time was intended to be entitled "Cultural Plunge". San Diego, CA: Author.

Nagda, B. A., Gurin, P., \& Lopez, G. E. (2003) Transformative pedagogy for democracy and social justice. Race Ethnicity \& Education, 6(2), 165-191.

Ponterotto, J. (1997). Multicultural counseling training: A competency model and national survey. In Pope-Davis, D. \& Coleman, H. (Eds.) Multicultural counseling competencies: Assessment, education and training, and supervision (pp. 111-130). Thousand Oaks: Sage Publications.

Robinson-Zanartu, C., Cook-Morales, V., Terry, L., \& Senour, M. N. (unpublished). 2004 department of counseling and school psychology outcomes study. San Diego, CA: College of Education, San Diego State University.

Robinson-Zanartu, C., Cook-Morales, V., Terry, L., \& Senour, M. N. (2004). [Department of counseling and school psychology outcomes study]. Unpublished raw data.

Sevig, T. D., \& Etzkorn, J. (2001). Transformative training: A yearlong multicultural counseling seminar for graduate students. Multicultural Counseling and Development, 29, 57-72.

Senour, M.N., (unpublished). 1998 CBB Employer and Supervisor Survey. San Diego, CA: College of Education, San Diego State University.

Senour, M.N., (unpublished). 2006 CBB Employer and Supervisor Survey. San Diego, CA: College of Education, San Diego State University.

Senour, M.N. (1998). [CBB Employer and Supervisor Survey]. Unpublished raw data.

Sfeir-Younis, L.F. (1995). Reflections on the teaching of multicultural courses. In D. Schoem, L. Frankel, X. Zuniga, \& E.A. Lewis(Eds.), Multicultural teaching in the university (pp.61-75). Westport, CT: Praeger

Sue, D.W., Arredondo, P., \& McDavid, R. J. (1992). Multicultural counseling competencies and standards: A call to the profession. Journal of Counseling and Development, 70, 477-486.

Sue, D.W., Bernier, J. E., Durran, A., Fienberg, L., Pedersen, P., Smith, E. J., \& VasquezNuttal, E. (1982). Position paper: Cross-cultural counseling competencies. The Counseling Psychologist, 10, 45-52. 
Appendix A

\section{SAN DIEGO STATE UNIVERSITY}

\section{Department of Counseling and School Psychology \\ Community-Based Block Program \\ San Diego, CA 91182-1179}

\section{Self-of-the-Counselor Comprehensive Exam 2008}

\section{DESCRIPTION:}

The purpose of this comprehensive exam is to assess your competence in conceptualizing and practicing personal growth that supports your professional growth and development in the interest of clients and communities.

\section{Student Learning Outcome Objectives:}

- Self-assess your personal identity development (include culture, sexuality, class, social justice, etc.) and recognize your effects on others.

- Self-assess whether your personal growth is in the interest of clients, communities, and social justice.

- Research and demonstrate the ability to implement self-care strategies for yourself as a counselor to help with stress management/reduction.

- Articulate interpersonal behaviors that impede effective functioning and professional development.

- Articulate resiliency and interpersonal strengths and their importance for professional development.

- Demonstrate your ability to conceptualize and implement self-care strategies for yourself as a counselor to help with stress management/reduction and to prevent burnout.

\section{DUE DATES:}

1st Draft Due Date: April 9, 2008

Last Day New Work Accepted for Spring 2008 Grading Period:

May 2, 2008

\section{REQUIREMENTS:}

\section{Choose one of the following two options:}

A. Completion of a Self-of-the-Counselor Portfolio which includes, but is not limited to: 
1. A reflection paper/project (no more than 10 pages) that demonstrates your competence in conceptualizing and practicing personal growth that supports your professional growth and development in the interest of clients and communities. Cite examples from artifacts from your CBB year, including but not limited to: interpersonal issues papers, autobiography of emotions, weekly reflections, other writings or projects, and feedback from others. Use them to:

a. Conceptualize your personal and interpersonal strengths and weaknesses and personal growth areas (include cultural, sexual, and other areas), how you came to realize that these are your issues, and why these are important for you to address for your professional growth and development.

b. What have you done to address your issues and areas of growth? How have you grown during the year?

c. How have you used yourself in the counseling booth and group processes to benefit others?

d. What effect(s) has your personal growth had on your work with your clients, other CBB learning community members, the community, and social justice?

2. Analyze and critique three articles or book chapters about the counseling profession and self-care, including a discussion of implications for your personal and professional growth (no more than 3 pages).

3. Research and implement a stress reduction/self-care method, such as HeartMath Emotional Management Techniques and include a 1-2 page description of its effect(s) on your personal and professional growth.

4. Relevant artifacts from your CBB personal growth experiences.

Or

B. Completion of a 25-page, APA formatted, Self-of-the-Counselor Research Paper which demonstrates your competence in conceptualizing and understanding personal growth that supports professional development in the interest of clients and communities. This paper should address a topic of your choice related to the concept of the "self-of-the-counselor" and it should include research and discussion not limited to the following questions:

1. Conceptually, what is the "self-of-counselor" and why is it important for professional development?

2. What is personal growth that supports counselor's professional development in the interest of clients and communities? 
3. What problems and issues should counselors address in order to be professionally competent?

\section{GRADING}

Projects and papers must be well thought out and include: a relevant integration of material from the sources utilized, graduate level writing skills, correct use of APA format, and academic integrity. You are encouraged to be creative and use this process for your own growth and development. Key content areas, APA formatting, paper structure and grammar will be rated from 1 (not acceptable) to 4 (very good). See the attached Self-of-the-Counselor Rubric for specific details. 
Appendix B

Self-of-the-Counselor Comprehensive Exam Rubric 2008

Date: Name of Student:

Faculty Evaluator:

\begin{tabular}{|c|c|c|c|c|c|c|c|}
\hline & $\begin{array}{c}\text { Not } \\
\begin{array}{l}\text { Acceptable } \\
=1\end{array}\end{array}$ & $\begin{array}{c}\text { Needs } \\
\text { Improvement } \\
=2\end{array}$ & $\begin{array}{c}\text { Acceptable } \\
=3\end{array}$ & $\begin{array}{l}\text { Very Good } \\
=4\end{array}$ & $\begin{array}{l}\text { Date: } \\
\text { Score } \\
\# 1\end{array}$ & $\begin{array}{l}\text { Date: } \\
\text { Score } \\
\text { \# } 2\end{array}$ & $\begin{array}{l}\text { Date: } \\
\text { Final } \\
\text { Score }\end{array}$ \\
\hline $\begin{array}{l}\text { Assessed your } \\
\text { personal identity } \\
\text { development } \\
\text { (including } \\
\text { culture, } \\
\text { sexuality, class, } \\
\text { social justice, } \\
\text { etc.). }\end{array}$ & $\begin{array}{l}\text { Did not assess } \\
\text { personal } \\
\text { identity } \\
\text { development } \\
\text { (culture, } \\
\text { sexuality, } \\
\text { class, social } \\
\text { justice, etc), } \\
\text { and/or } \\
\text { components of } \\
\text { thesis are } \\
\text { unclear and } \\
\text { information } \\
\text { appears } \\
\text { thrown } \\
\text { together, } \\
\text { haphazard. }\end{array}$ & $\begin{array}{l}\text { Addressed } \\
\text { some } \\
\text { components of } \\
\text { the Self-of- } \\
\text { the-Counselor } \\
\text { Comp } \\
\text { superficially. } \\
\text { Thesis is clear, } \\
\text { but supporting } \\
\text { information is } \\
\text { disconnected. }\end{array}$ & $\begin{array}{l}\text { Personal } \\
\text { identity } \\
\text { development } \\
\text { information } \\
\text { relates to a } \\
\text { clear thesis; } \\
\text { many relevant } \\
\text { points, but } \\
\text { they are } \\
\text { somewhat } \\
\text { unstructured. }\end{array}$ & $\begin{array}{l}\text { Exceptional } \\
\text { use of material } \\
\text { related to } \\
\text { personal } \\
\text { identity } \\
\text { development } \\
\text { that clearly } \\
\text { relates to a } \\
\text { focused thesis; } \\
\text { abundance of } \\
\text { various } \\
\text { supporting } \\
\text { materials. }\end{array}$ & & & \\
\hline
\end{tabular}




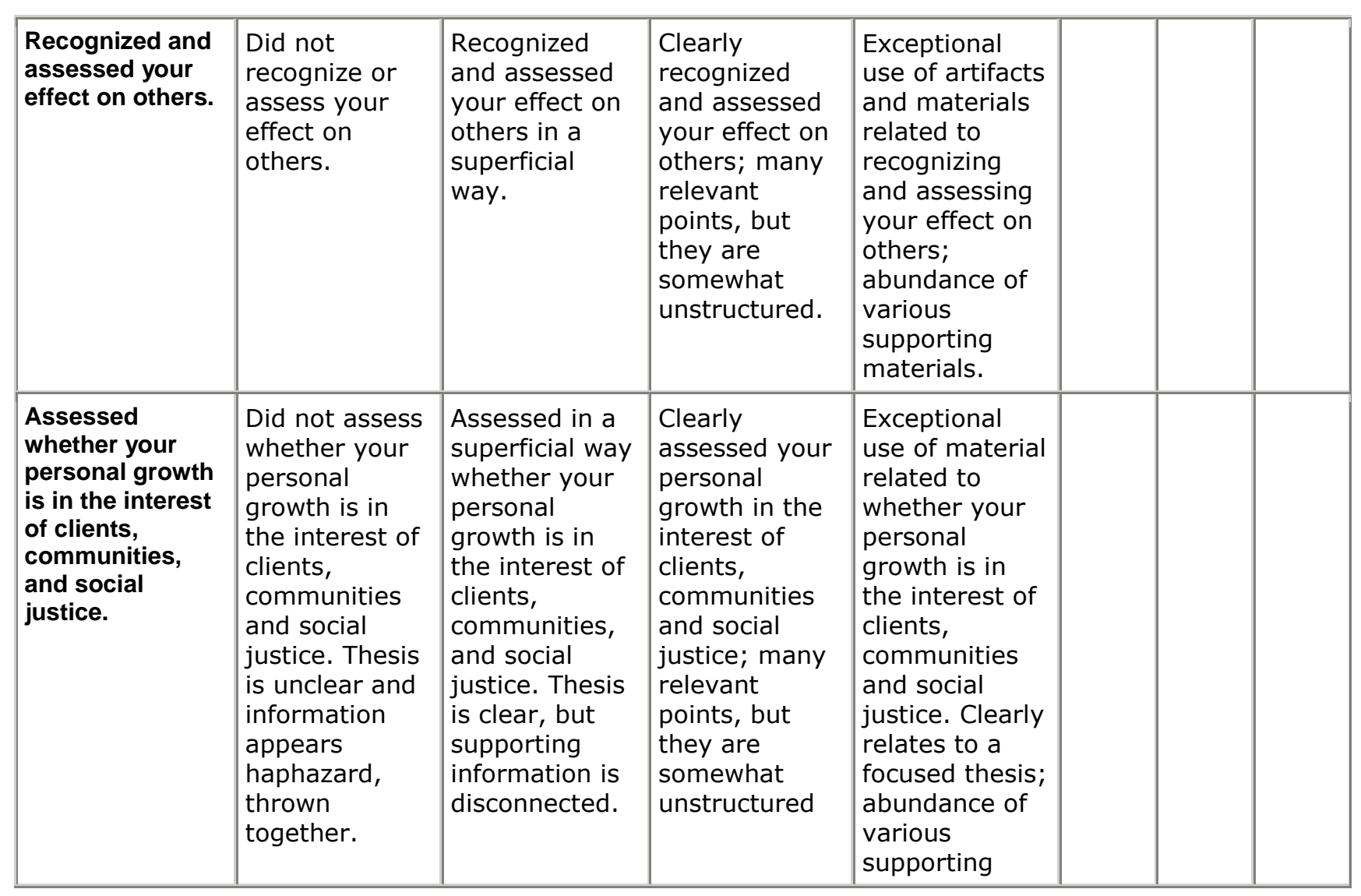




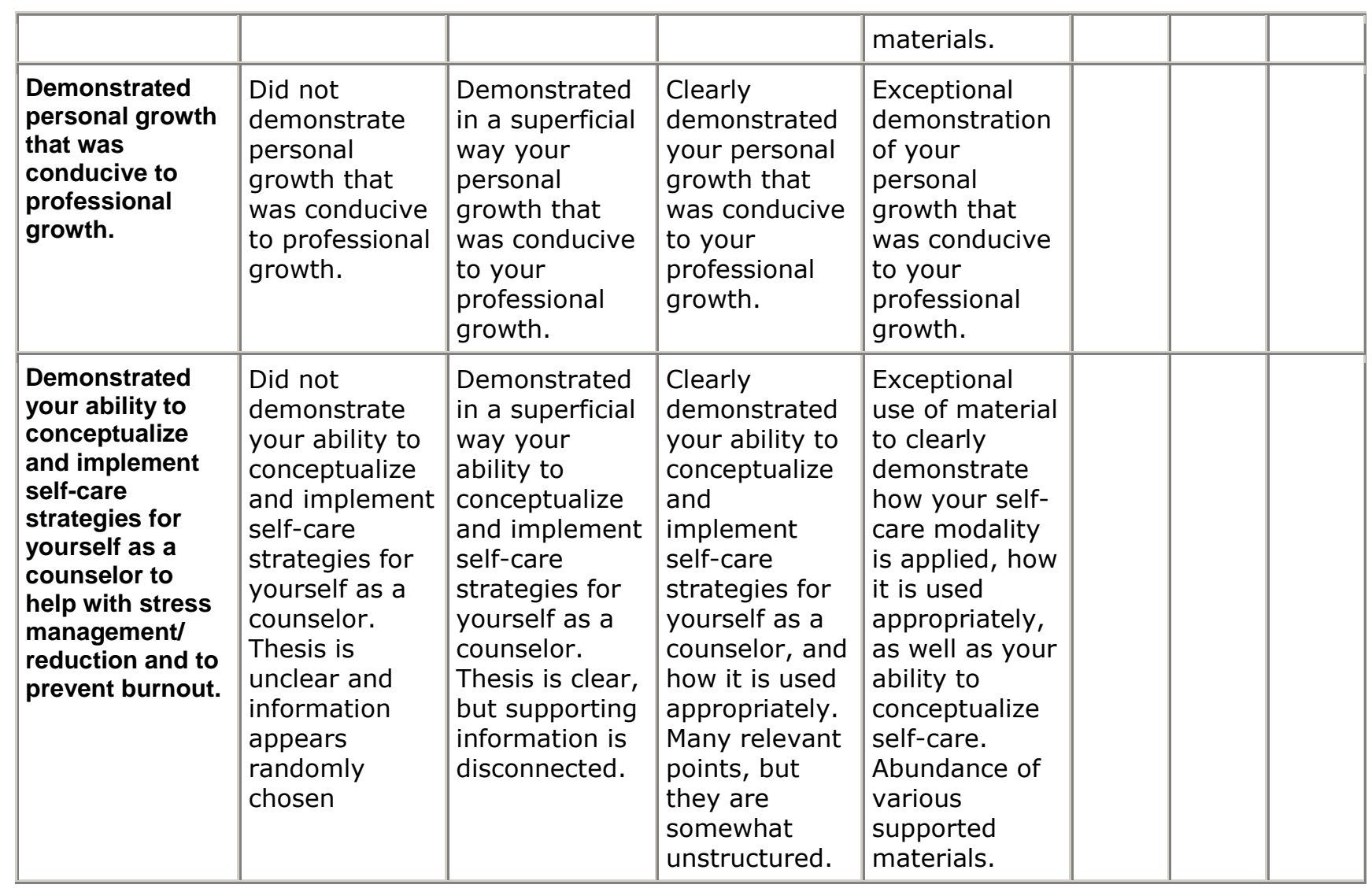




\begin{tabular}{|c|c|c|c|c|c|c|c|}
\hline $\begin{array}{l}\text { REFERENCES } \\
\text { AND } \\
\text { MULTICULTUR } \\
\text { AL CONTENT } \\
\text { CRITERIA FOR } \\
\text { ALL PAPERS \& } \\
\text { PROJECTS }\end{array}$ & $\begin{array}{c}\text { Not } \\
\begin{array}{l}\text { Acceptable } \\
=1\end{array}\end{array}$ & $\begin{array}{c}\text { Needs } \\
\text { Improvemen } \\
t=2\end{array}$ & $\begin{array}{c}\text { Acceptable } \\
=3\end{array}$ & $\begin{array}{l}\text { Very Good } \\
=4\end{array}$ & $\begin{array}{c}\text { Date: } \\
\text { Score } \\
\# 1\end{array}$ & $\begin{array}{l}\text { Date: } \\
\text { Scor } \\
\text { e \# } 2\end{array}$ & $\begin{array}{l}\text { Date: } \\
\text { Final } \\
\text { Score }\end{array}$ \\
\hline $\begin{array}{l}\text { Paper, } \\
\text { Presentation, } \\
\text { Use of } \\
\text { Artifacts or } \\
\text { Project } \\
\text { References }\end{array}$ & $\begin{array}{l}\text { No references } \\
\text { or artifacts; } \\
\text { incorrect } \\
\text { references. }\end{array}$ & $\begin{array}{l}\text { Few } \\
\text { references and } \\
\text { artifacts; or } \\
\text { some incorrect } \\
\text { references. }\end{array}$ & $\begin{array}{l}\text { Use of } \\
\text { references and } \\
\text { artifacts } \\
\text { indicate some } \\
\text { research. }\end{array}$ & $\begin{array}{l}\text { Use of } \\
\text { references and } \\
\text { artifacts } \\
\text { indicate } \\
\text { substantial } \\
\text { research. }\end{array}$ & & & \\
\hline APA Style & $\begin{array}{l}\text { APA style was } \\
\text { not used, or } \\
\text { only } \\
\text { minimally. }\end{array}$ & $\begin{array}{l}\text { Some use of } \\
\text { APA style, but } \\
\text { many } \\
\text { mistakes and } \\
\text { omissions. }\end{array}$ & $\begin{array}{l}\text { Use of APA } \\
\text { style is } \\
\text { evident, } \\
\text { however a few } \\
\text { errors are } \\
\text { present. }\end{array}$ & $\begin{array}{l}\text { Thorough, } \\
\text { accurate, } \\
\text { appropriate } \\
\text { use of APA } \\
\text { style } \\
\text { throughout } \\
\text { project or } \\
\text { document. }\end{array}$ & & & \\
\hline
\end{tabular}




\begin{tabular}{|c|c|c|c|c|c|c|c|}
\hline $\begin{array}{l}\text { PAPER } \\
\text { CRITERIA }\end{array}$ & & & & & $\begin{array}{l}\text { Date: } \\
\text { Score } \\
\# 1\end{array}$ & $\begin{array}{l}\text { Date: } \\
\text { Score } \\
\text { \#2 }\end{array}$ & $\begin{array}{l}\text { Date: } \\
\text { Final } \\
\text { Score }\end{array}$ \\
\hline $\begin{array}{l}\text { Sentence } \\
\text { Structure }\end{array}$ & $\begin{array}{l}\text { Unclear, } \\
\text { incorrect, } \\
\text { and/or } \\
\text { ineffective } \\
\text { sentence } \\
\text { structure. }\end{array}$ & $\begin{array}{l}\text { Simplistic } \\
\text { and/or } \\
\text { awkward } \\
\text { sentence } \\
\text { structure. }\end{array}$ & $\begin{array}{l}\text { Organized and } \\
\text { complex } \\
\text { sentence } \\
\text { structure that } \\
\text { has some } \\
\text { stylistic } \\
\text { variation. }\end{array}$ & $\begin{array}{l}\text { Sentence } \\
\text { structure is } \\
\text { varied in } \\
\text { composition } \\
\text { and length. }\end{array}$ & & & \\
\hline Grammar & $\begin{array}{l}\text { Multiple } \\
\text { grammatical } \\
\text { and stylistic } \\
\text { errors. }\end{array}$ & $\begin{array}{l}\text { Some errors in } \\
\text { grammar } \\
\text { and/or format } \\
\text { that do not } \\
\text { interfere with } \\
\text { clarity. }\end{array}$ & $\begin{array}{l}\text { Few } \\
\text { grammatical } \\
\text { and/or stylistic } \\
\text { errors. }\end{array}$ & $\begin{array}{l}\text { Nearly error- } \\
\text { free which } \\
\text { reflects clear } \\
\text { understanding } \\
\text { and thorough } \\
\text { proofreading. }\end{array}$ & & & \\
\hline Vocabulary & $\begin{array}{l}\text { Apparent } \\
\text { confusion with } \\
\text { the use of } \\
\text { language. }\end{array}$ & $\begin{array}{l}\text { Simplistic } \\
\text { and/or unclear } \\
\text { language. }\end{array}$ & $\begin{array}{l}\text { Effective } \\
\text { language. }\end{array}$ & $\begin{array}{l}\text { Rich and } \\
\text { precise } \\
\text { language. }\end{array}$ & & & \\
\hline Thesis & $\begin{array}{l}\text { There is no } \\
\text { clear purpose } \\
\text { of the paper; } \\
\text { seemingly } \\
\text { little attempt }\end{array}$ & $\begin{array}{l}\text { Attempt to } \\
\text { create a thesis } \\
\text { statement and } \\
\text { communicate } \\
\text { the purpose }\end{array}$ & $\begin{array}{l}\text { Evidence of } \\
\text { thesis can be } \\
\text { found and } \\
\text { author } \\
\text { generally }\end{array}$ & $\begin{array}{l}\text { Establishes } \\
\text { thesis and } \\
\text { maintains clear } \\
\text { purpose via } \\
\text { suitable voice }\end{array}$ & & & \\
\hline
\end{tabular}




\begin{tabular}{|l|l|l|l|l|l|l|}
\hline & $\begin{array}{l}\text { to create a } \\
\text { thesis } \\
\text { statement. }\end{array}$ & throughout. & $\begin{array}{l}\text { maintains } \\
\text { purpose } \\
\text { through } \\
\text { suitable voice } \\
\text { and/or tone. }\end{array}$ & and tone. & & \\
\hline $\begin{array}{l}\text { Meaningful } \\
\text { Development } \\
\text { of Ideas }\end{array}$ & $\begin{array}{l}\text { Ideas are } \\
\text { unclear } \\
\text { and/or not } \\
\text { well } \\
\text { developed. }\end{array}$ & $\begin{array}{l}\text { Unelaborated } \\
\text { ideas that are } \\
\text { not fully } \\
\text { explained or } \\
\text { supported; } \\
\text { repetitive } \\
\text { details. }\end{array}$ & $\begin{array}{l}\text { Depth of } \\
\text { thought } \\
\text { supported by } \\
\text { elaborated, } \\
\text { relevant } \\
\text { supportive } \\
\text { evidence } \\
\text { provides clear } \\
\text { vision of the } \\
\text { idea; contains } \\
\text { details. }\end{array}$ & $\begin{array}{l}\text { Depth and } \\
\text { complexity of } \\
\text { thought } \\
\text { supported by } \\
\text { rich, pertinent } \\
\text { details; } \\
\text { supporting } \\
\text { evidence leads } \\
\text { to high-level } \\
\text { idea } \\
\text { development. }\end{array}$ & & \\
\hline $\begin{array}{l}\text { Organization of } \\
\text { Paper }\end{array}$ & $\begin{array}{l}\text { Weak } \\
\text { organization } \\
\text { of ideas. }\end{array}$ & $\begin{array}{l}\text { Somewhat } \\
\text { unfocused } \\
\text { and/or unclear. }\end{array}$ & $\begin{array}{l}\text { Logical } \\
\text { organization of } \\
\text { ideas. }\end{array}$ & $\begin{array}{l}\text { Careful and } \\
\text { relevant } \\
\text { organization of } \\
\text { ideas. }\end{array}$ & & \\
\hline
\end{tabular}

